\title{
End-Member Selection in Two-Component Isotope-Based Hydrograph Separation
}

\author{
Samuel Bansah ${ }^{1,2,3,4,5^{*}}$, Jonathan Quaye-Ballard6, Samuel Andam-Akorful6, Edward Bam ${ }^{7}$, \\ Geophrey K. Anornu ${ }^{8}$
}

\author{
${ }^{1}$ Department of Geological Engineering, Kwame Nkrumah University of Science and Technology, Kumasi, Ghana \\ ${ }^{2}$ Isotope Hydrology Research Program (IHReP), Kumasi, Ghana \\ ${ }^{3}$ Department of Geological Sciences, University of Manitoba, Winnipeg, Canada \\ ${ }^{4}$ Manitoba's Watershed Systems Research Program, Manitoba, Canada \\ ${ }^{5}$ Center for Earth Observation Science, University of Manitoba, Winnipeg, Manitoba, Canada \\ ${ }^{6}$ Department of Geomatic Engineering, Kwame Nkrumah University of Science and Technology, Kumasi, Ghana \\ ${ }^{7}$ Global Institute of Water Security, University of Saskatchewan, Saskatoon, Canada \\ ${ }^{8}$ Department of Civil Engineering, Kwame Nkrumah University of Science and Technology, Kumasi, Ghana \\ Email: *bansahs@myuma nitoba.ca, *sbansah.coe@knust.edu.gh
}

How to cite this paper: Bansah, S., Quaye-Ballard, J., Andam-Akorful, S., Bam, E. and Anornu, G.K. (2019) End-Member Selection in Two-Component Isotope-Based Hydrograph Separation. Open Journal of Modern Hydrology, 9, 41-53. https://doi.org/10.4236/ojmh.2019.92003

Received: February 16, 2019

Accepted: April 15, 2019

Published: April 18, 2019

Copyright (C) 2019 by author(s) and Scientific Research Publishing Inc. This work is licensed under the Creative Commons Attribution International License (CC BY 4.0).

http://creativecommons.org/licenses/by/4.0/

\section{(c) (i) Open Access}

\begin{abstract}
The science that underpins our knowledge and understanding of Isotope-Based Hydrograph separation (IHS) has gained grounds, over the last few decades, in the identification of streamflow sources. However, challenges still exist in identifying appropriate tracers and the right combination of end-members for the IHS process. In a two-component IHS analysis, the application of the dual isotopes tracers, $\delta^{18} \mathrm{O}$ and (or) $\delta^{2} \mathrm{H}$, is regarded as the simplest method. We undertook an IHS study within a nested system of eight Prairie watersheds located in South central Manitoba, Canada. The work evaluated about 17,000 results emanating from the application of a combination of two potential tracers $\left(\delta^{18} \mathrm{O}\right.$ and $\left.\delta^{2} \mathrm{H}\right)$ and eight each of potential "old" and "new" water end-members in a two-component IHS process. The outcome showed occurrences of many mathematically possible but hydrologically unacceptable IHS results. The observation was particularly predominant within relatively larger perennial sub-catchments of the watershed. It is also shown that inter-site sub-catchment isotopic end-member transferability is possible within watersheds of similar physio-hydrographic characteristics. We suggest that a careful evaluation of the physio-hydrographic characteristics of catchments be considered in IHS studies in addition to the recommended guidelines in the selection of tracers and end-members.
\end{abstract}

\section{Keywords}

Hydrograph Separation, Oxygen-18, Deuterium, Stable Isotopes, 
End-Member Definitions, Canadian Prairies

\section{Introduction}

The science that involves the identification of various sources of streamflow contributions has improved since the advent and integration of environmental isotopes, especially $\delta^{18} \mathrm{O}$ and $\delta^{2} \mathrm{H}$, into watershed science. Identifying sources of streamflow can be beneficial in studies involving the evaluation of drought conditions [1], atmospheric trends [2] [3], flow regimes [4], nutrient and contaminant sources [5], amongst others. The identification of streamflow sources, in the context of environmental isotopes, is achieved through a process called Isotope-based hydrograph separation (IHS), a method which involves solving a couple of multi-component mass balance equations with its underpinning assumptions detailed in earlier works by [6] and [7] [8]. The variables $(\delta)$ in the mass balance equations are informed by the end-member (End-M) choices in the hydrograph separation process. The choice and use of specific End-Ms invariably translate into the computed proportions of streamflow contributions coming from the various sources. Selecting appropriate End-Ms, the application of which will lead to results that will adduce confidence in usage for watershed management decision making, is thus critical. Emerging results from recent studies (e.g., [9]), however, suggest that making the "right" choice of End-Ms may not be an easy and straightforward process. In fact, outcomes from the IHS work by [9] - and the associated uncertainties emanating from the computed IHS results-suggest that, aside the basic understanding of the underlying principles of the science governing the IHS studies, a clear appreciation of the effects of geographic, geologic and seasonal climatic dynamics on the results of IHS may be needed. This is particularly critical for semi arid regions such as the Canadian Prairies where inter-seasonal and annual shifts in climatic dynamics can strongly influence End-M concentrations leading to rapid temporal changes in IHS results.

This study further elucidates the spatio-temporal dynamics of the IHS outcomes emerging from the End-M choices outlined in the work of [9]. We evaluate how the End-M scenario (sensu [9]) choices contribute to mathematically possible (i.e., results that also include values that are less than 0 or greater than 1) hydrograph separation results. We also consider if seasonal and physio-hydrogeographic dynamics at a site can influence the choice of End-Ms available for IHS. An evaluation is also made to test if there is any statistical significant association of IHS results over all the scenarios. To this end, the main objective of this paper was to evaluate the dynamics of the potential "pools" of end-members that may be available to watershed scientists in the context of an isotope based hydrograph separation (IHS) process and catchment hydro-physiographic characteristics. We computed 17040 IHS results obtained by the application of two tracers $\left(\delta^{18} \mathrm{O}\right.$ and $\left.\delta^{2} \mathrm{H}\right)$, eight "old" water End-Ms, and eight "new" water End-Ms within eight nested systems of Prairie watersheds. One combination of choice of 
a tracer (either $\delta^{18} \mathrm{O}$ or $\delta^{2} \mathrm{H}$ ), an "old" water End-M, and a "new" water End-M form a scenario. In this light, potential quasi-surrogate groups of End-Ms can be isolated for IHS studies in semi arid regions such as in the Canadian Prairies.

\section{Methods}

Our research was undertaken in a nested system of a $74.41 \mathrm{~km}^{2}$ Prairie watersheds comprising of eight outlets (Figure 1(a)) and located within the Prairies ecozone in south central Manitoba, Canada. The ecozone is characterized by semi-arid to sub-humid temperate conditions, i.e., cold lengthy winters and short cool summers [10]. The watershed comprises of the "MS" sites, which are relatively smaller sub catchments and are located above the escarpment, the HWY240 site atop of which the escarpment trends, and the Miami site which forms the final outlet of the whole watershed (Figure 1(a)). The escarpment, which marks the boundary of Glacial Lake Agassiz, is composed of glacial deposits as an outcome of successive glaciation and morainal activities [11]. The HWY240 site forms the only perennial outlet among the studied catchments and underlaid by coarse grained silt, sand and gravel deposits (Figure 1(c)). The watershed is generally composed of cropland vegetation with forested patches within some portions - the HWY240 site having the most forest (Figure 1(b)).

Each outlet was equipped with rain collectors (Texas Electronic Tipping Bucket rain gages [TE525-L, 0.01 of an inch precision]) and different types of weirs-synchronised with a Campbell Scientific snow and water depth sensor SR50A (1 cm accuracy) - for discharge measurements. Discharge was measured at a frequency of 15 minutes, and later transformed into daily averages, while precipitation measurement took place daily. Each of the sites was equipped with automatic water samplers for collecting streamwater and piezometers for groundwater sampling. Snow lysimeters were used for snowmelt sample collection. In all, a total of 92 snow and snowmelt samples, 86 rain samples, 143 shallow and intermediate groundwater samples, 9 deep groundwater samples and 213 stream water samples were collected and tested for $\delta^{18} \mathrm{O}$ and $\delta^{2} \mathrm{H}$.

The $\delta^{18} \mathrm{O}$ and $\delta^{2} \mathrm{H}$ tracer results from the isotopic sampling and analyses ${ }^{1}$ of the stream, groundwater (including shallow, intermediate, and deep sources), and precipitation (including snowpack, melt, and rain) were used as variables in a two-component IHS process. The process relied on the steady-state mass balance equations of water and concentration equilibrium [12] (Equation (1) and Equation (2)), to separate the stream hydrographs into "old" water (i.e., water that existed within the watershed before the onset of the current precipitation) and "new" water (i.e., water brought in by the current precipitation event). The ${ }^{1}$ Picarro ${ }^{\mathrm{TM}}$ Liquid Water Isotope Analyzer (LWIA, model L2130-i), located at the Manitoba's WSRP lab in Canada, was used to analyze the samples. The LWIA works on a Cavity Ring-Down Spectroscopy (CRDS) technology. The measured $\delta$ values were recorded relative to VSMOW standard [18] with a precision of $0.025 \%$ and $0.1 \%$ for $\delta^{18} \mathrm{O}$ and $\delta^{2} \mathrm{H}$, respectively. 


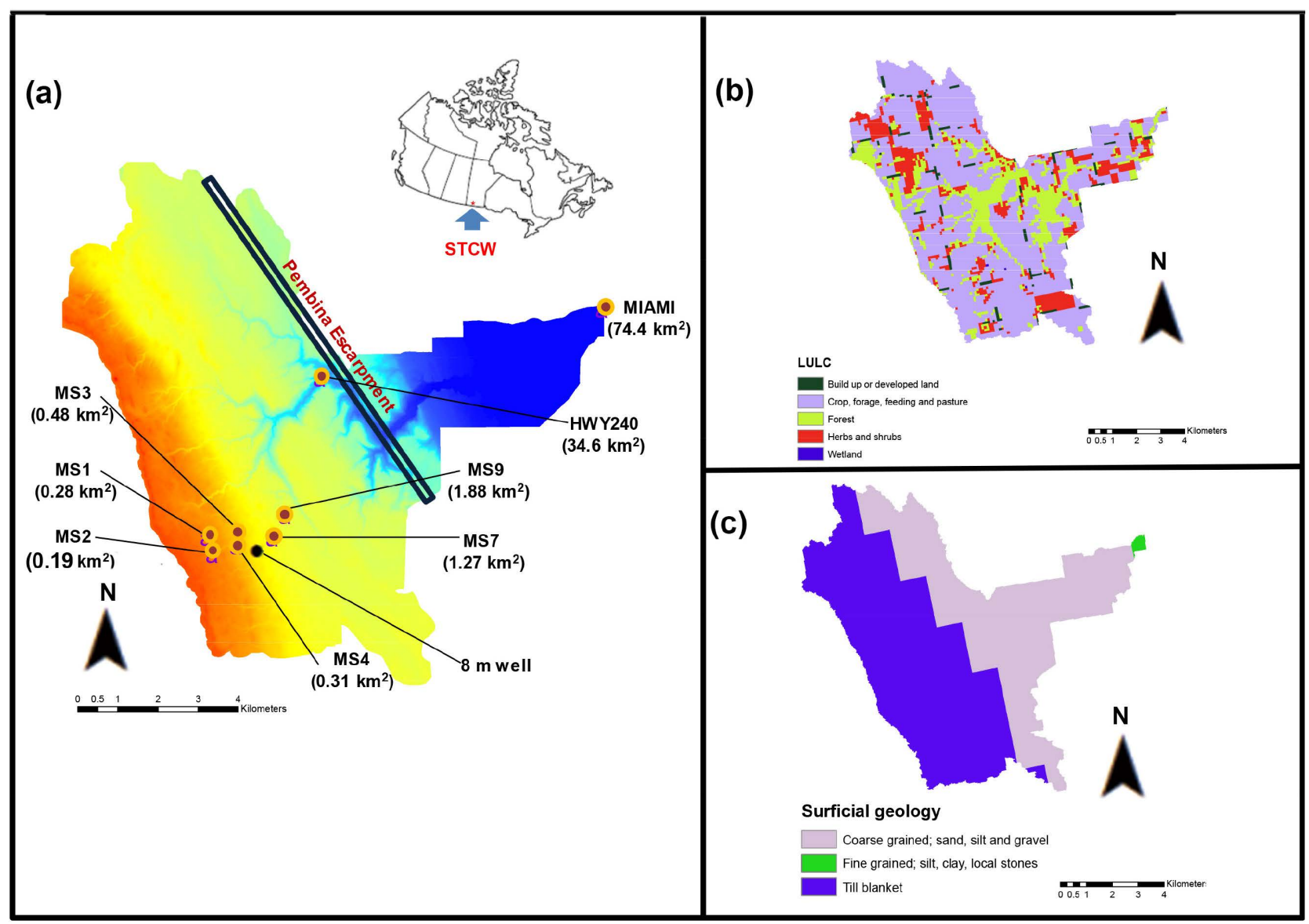

Figure 1. (a) $1 \mathrm{~m}$ horizontal resolution digital elevation model of the South Tobacco Creek Watershed (STCW) located in south central Manitoba, Canada. Sub-catchment outlets (i.e., streamwater sampling locations) are indicated as filled circles with their respective watershed areas. m.a.s.l.: meters above sea level; (b) Land use and land cover characteristics of the STCW; (c) General surficial geology of the watershed.

End-M selection and IHS technique, outlined in [13] and then [9], were followed in the separation of each stream hydrograph.

$$
\begin{gathered}
Q_{\text {stream }}=Q_{\text {old }}+Q_{\text {new }} \\
Q_{\text {stream }} \delta_{\text {stream }}=Q_{\text {old }} \delta_{\text {old }}+Q_{\text {new }} \delta_{\text {new }}
\end{gathered}
$$

where $Q$ is discharge, $\delta$ is the isotopic ratio of a sample relative to standard, subscripts stream, old, and new refer to the streamwater, "old" water, and "new" water.

Transformation of (1) and (2) above yields the proportions of "old" $\left(P R O P_{\text {old }}\right)$ and "new" ( $\left.P R O P_{\text {new }}\right)$ water in the stream as outlined in (3) and (4) below:

$$
\begin{gathered}
P R O P_{\text {old }}=\frac{\delta^{18} O_{\text {stream }}-\delta^{18} O_{\text {new }}}{\delta^{18} O_{\text {old }}-\delta^{18} O_{\text {new }}} \\
P R O P_{\text {new }}=1-P R O P_{\text {old }}
\end{gathered}
$$

Establishment of potential "pools" of scenarios based on the combination of one "new" water End-M definition, one "old" water End-M definition, and one 
tracer (either $\delta^{18} \mathrm{O}$ or $\delta^{2} \mathrm{H}$ ) were assessed. In all, there were eight each of potential "new" and "old" water End-Ms definitions (Table 1) with each selection of one "new" water End-M, one "old" water End-M, and one tracer forming a scenario. There were forty each of $\delta^{18} \mathrm{O}$-based and $\delta^{2} \mathrm{H}$-based scenarios with the former numbered from 1 to 40 while the latter was numbered from 41 to 80. [13] recommendation regarding the "piece- and step-wise" End-M shifts in the IHS process was adopted. In all, 17,040 IHS computations were attempted across all sites (i.e., 213 stream water samples $\times 80$ scenarios). To estimate daily fluxes of "new" and "old" water in each outlet, the average $\delta^{18} \mathrm{O}$ and $\delta^{2} \mathrm{H}$ values across all the 80 scenarios were multiplied by the daily discharge values. To assess statistical significance between IHS results from the application of the same scenario across the eight sites, we performed a Spearman's rank correlation analysis at the 95\% significance level.

\section{Results}

\subsection{Spatio-Temporal Distribution of "Old" Water Fractions (PROP old)}

There was a general increase in the fraction of "old" water $\left(P R O P_{\text {old }}\right)$ at all the outlets as the water year progresses from April until October (Figure 2). This trend is consistent with findings from other studies, albeit in studies within humid catchments (e.g., [14] [15]). At site HWY240, however, high $P R O P_{\text {old }}$ was originally present in the stream channel at the onset of the freshet ${ }^{2}$, and sharply decreased as the season progressed, before finally beginning to increase again on the $21^{\text {st }}$ of May through to the end of the water year (Figure 2). There again at site HWY240, in contrast with the other sites, $P R O P_{\text {old }}$ was generally higher especially within the early and late spring seasons (up to June $21^{\text {st }}$ ) - on most of the sampling days (Figure 2). This observation at site HWY240 is further affirmed by the high proportion of $P R O P_{\text {old }}$ fluxes during the freshet in comparison to the other sites (Figure 3). $P R O P_{\text {old }}$ fluxes at all the sites were generally lower than the $P R O P_{\text {new }}$ counterpart during the freshet; only increasing, in response to temperature rise, as the season progressed until the end of the water year in October (Figure 3).

\subsection{Scenario-Based Number of Hydrograph Separations}

The number of scenarios that led to mathematically possible (including less than 0 and greater than 1) isotope based hydrograph separation (IHS) results appear to be smaller at majority of the sites located above the escarpment (i.e., sites MS1, MS2, MS3, and MS4) in contrast to the sites located at Miami and HWY240 (Figure 1(a) \& Figure 4(a)). This observation appears out of concert with the actual number of IHS results (within 0 and 1) that were obtained out of the total number of stream samples collected from each site. In that regard, the aforementioned "above escarpment sites" yielded more IHS results compared ${ }^{2} \mathrm{~A}$ term used in North America to describe the spring thaw resulting from melting of ice and snow within a watershed. 
Table 1. List of "new" water and "old" water end-member definitions applied in this study. Their combinations with either $\delta^{18} \mathrm{O}$ or $\delta^{2} \mathrm{H}$ tracers led to 1740 hydrograph separation results.

\begin{tabular}{|c|c|}
\hline "New" water end-member Definitions & “Old" water end-member Definitions \\
\hline 1) Most recent snowpack sample & 1) Most recent shallow groundwater samples from $0.6 \mathrm{~m}$ piezometer \\
\hline 2) Most recent meltwater sample & 2) Most recent intermediate groundwater sample from $1.5 \mathrm{~m}$ piezometer \\
\hline 3) Seasonal average of meltwater samples & $\begin{array}{l}\text { 3) Average of most recent } 0.6 \mathrm{~m} \text { shallow ground water and } 1.5 \mathrm{~m} \text { deep ground } \\
\text { water samples }\end{array}$ \\
\hline 4) Seasonal average of snowpack samples & 4) Seasonal average of shallow groundwater samples \\
\hline 5) Average of most recent snow, melt and rain samples & 5) Seasonal average of intermediate groundwater samples \\
\hline 6) Average of most recent melt and rain samples & 6) Seasonal average of shallow groundwater and intermediate groundwater samples \\
\hline 7) Most recent rain samples & 7) Stream water sample at baseflow \\
\hline 8) Seasonal average of rain samples & 8) Deep groundwater sample from $8 \mathrm{~m}$ well \\
\hline
\end{tabular}

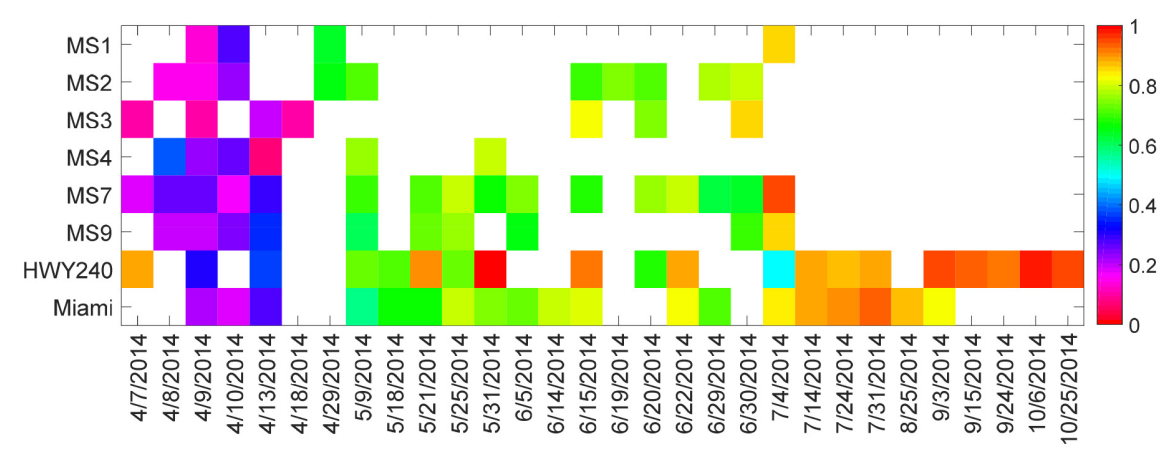

Figure 2. Spatio-temporal distribution of "old" water in streamflow across all scenarios for all sampling days of the 2014 water year. "old" water is computed as averages across all the 80 scenarios considered for each sampling day. Empty white cells indicate either hydrograph separation results that are below zero or above 1, or days on which the stream channel was dry.

with the sites near (or at) the final outlet of the watershed (Figure 4(b)). A look at the temporal dynamics of number of scenarios that led to successful IHS results (between 0 and 1) across each of the sites show that more choices of scenarios are available at the headwater site MS1 compared with sites HWY240 and Miami; in fact, HWY240 has the minimum number of scenarios available to pick from in performing IHS (Figure 5) on a sampled streamwater. This observation at site MS1 is consistent even across tracer dynamics $\left(\delta^{18} \mathrm{O}\right.$ versus $\left.\delta^{2} \mathrm{H}\right)$; there are about equal amounts of scenarios $\left(1-40\right.$ for $\delta^{18} \mathrm{O}$-base and 41-80 for $\delta^{2} \mathrm{H}$-base)-almost forming a mirror image-to choose from when we consider each tracer (Figure 6).

There appears to be a dominance of strong to very strong significant associations of $P R O P_{\text {old }}$ results-obtained from the application of the same scenario across the eight sites-when correlation analysis (at the 95\% significance level) of all the results across the 80 scenarios was performed (Figure 7(a)). It should, however, be noted that the existence of significant correlations between 

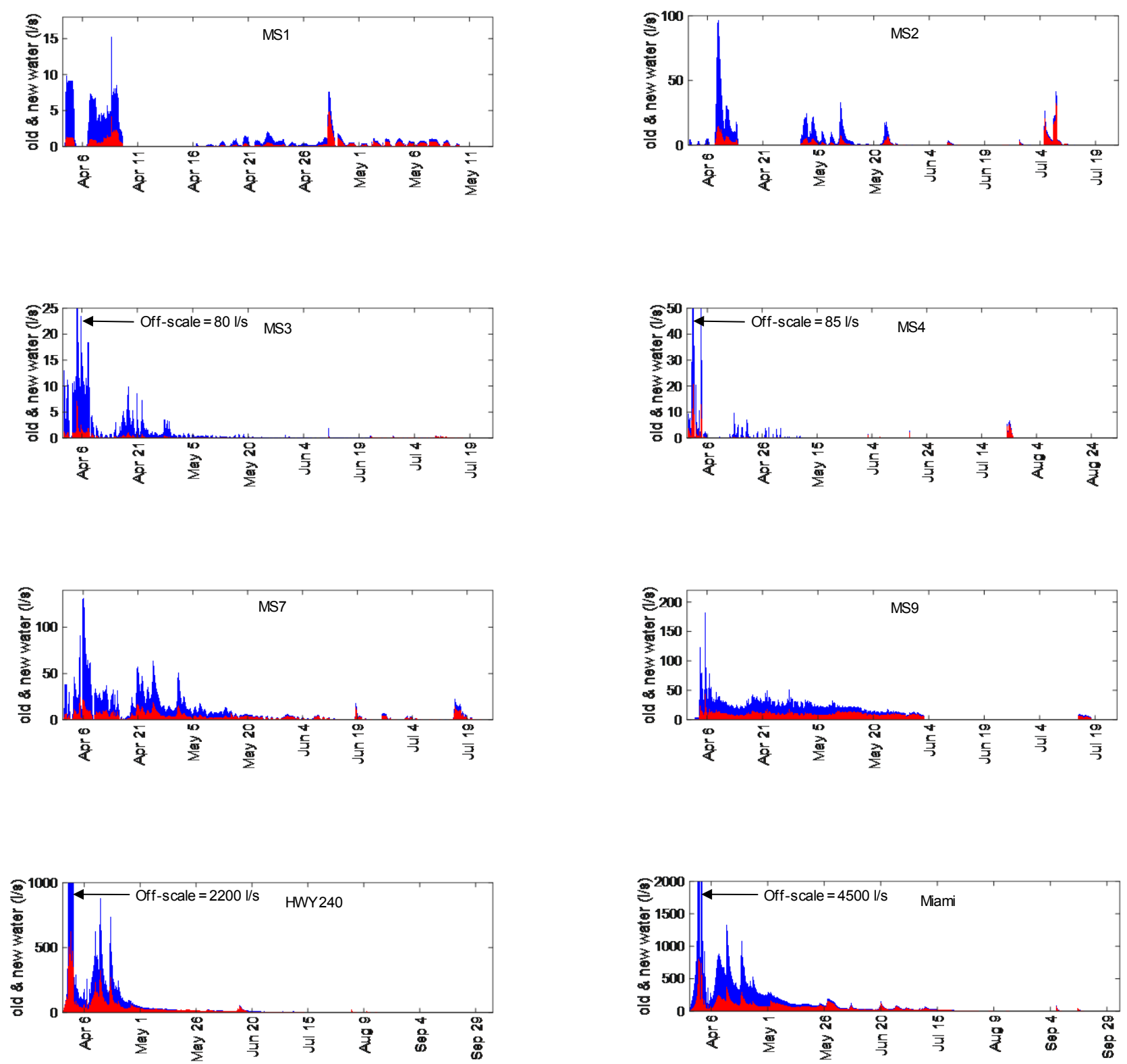

\section{New water $\square$ old water}

Figure 3. Fluxes of "old" and "new" water in streamflow within the outlets in the water year. To increase resolution and readability, scales on both $\mathrm{x}$ and $\mathrm{y}$ axes vary from site to site.

$\delta^{18} \mathrm{O}$-based $P R O P_{\text {old }}$ results and their $\delta^{2} \mathrm{H}$-based counterparts are not out of the ordinary, especially for some of the sites (MS9 and Miami). From results of the works of [9], an almost perfect associations (from the 1:1 referenced line scatter plots) existed between the $\delta^{18} \mathrm{O}$ - and $\delta^{2} \mathrm{H}$-based $P R O P_{\text {old }}$ results at sites MS9-which is a wind sheltered site-and the outlet at Miami-which is a relatively flat catchment. We also see, in this current work, significant associations between the $P R O P_{\text {old }}$ results (computed across all the scenarios, Figure $7(\mathrm{~b})$ ) of sites MS9 and Miami ( $\mathrm{p}$ value $=0.001)$, MS9 and MS7 $(\mathrm{p}$ value $=0.005)$ and MS7 and Miami $(\mathrm{p}$ value $=0.001)$. 


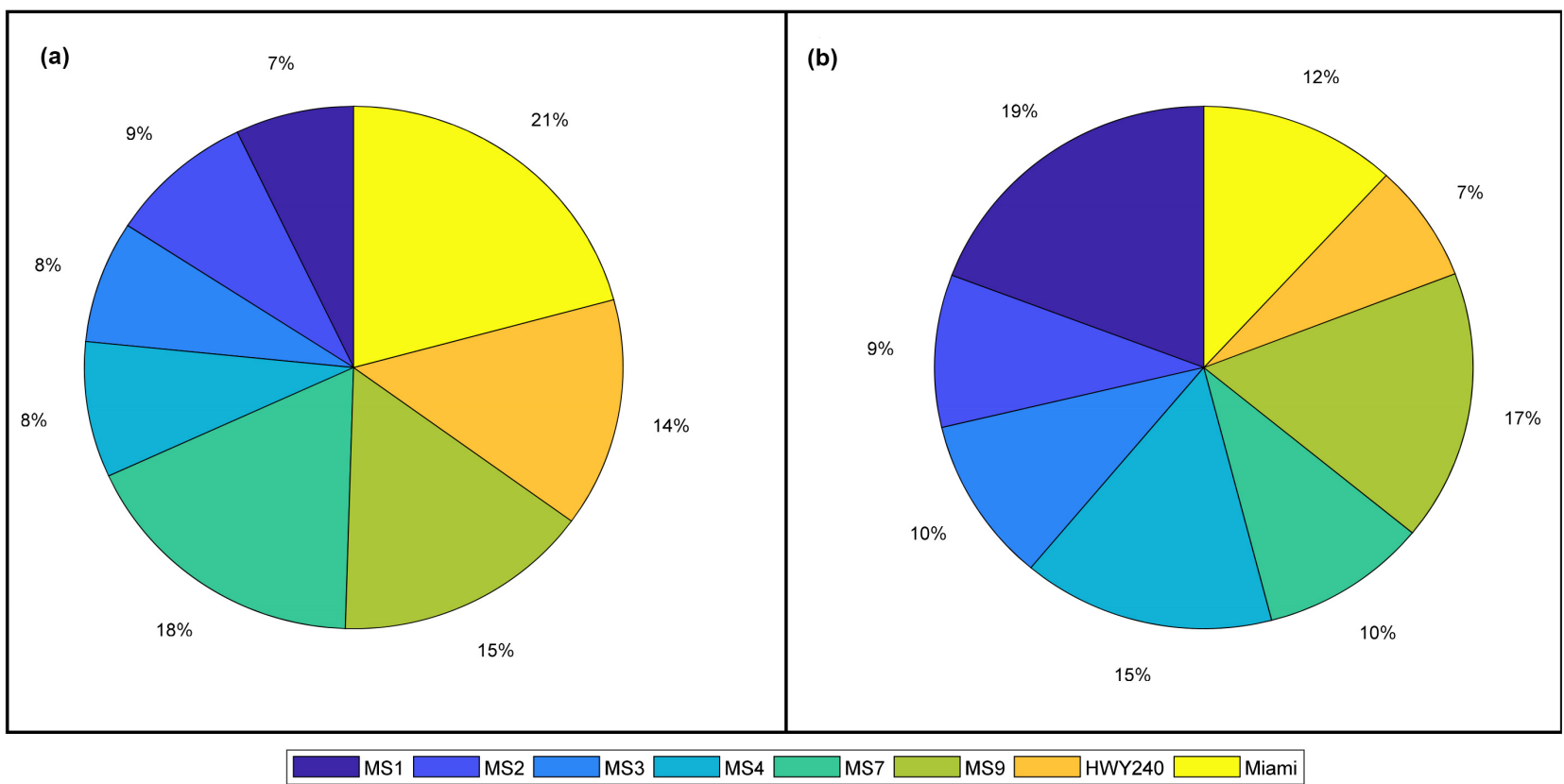

Figure 4. Spatial distributions of (a) the total number of scenarios that resulted in mathematically possible IHS and (b) number of IHS results obtained out of the total samples collected.
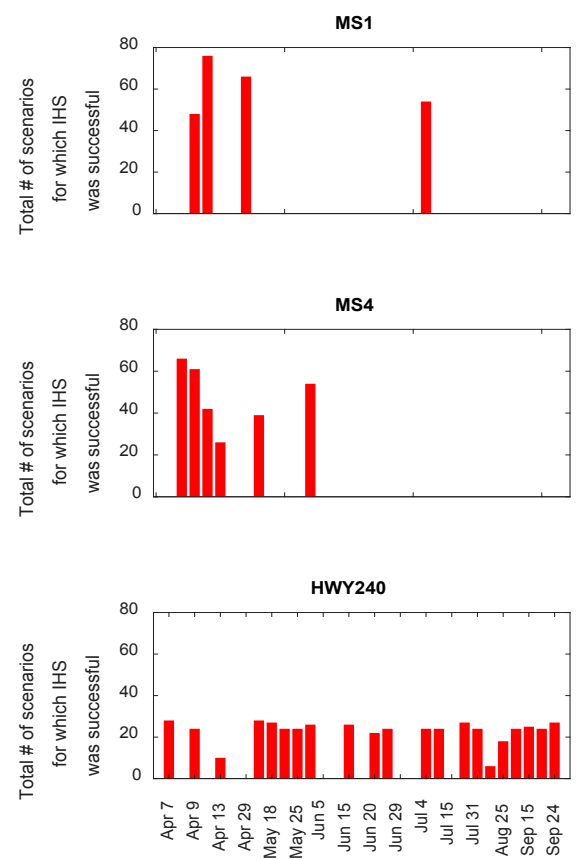

MS2

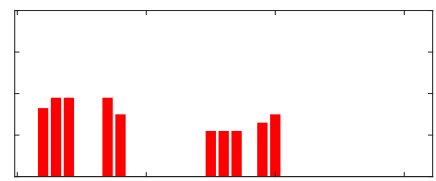

MS7

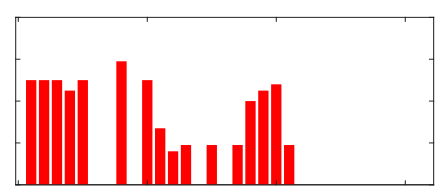

Miami

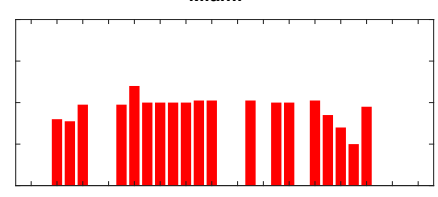

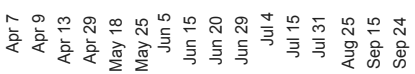
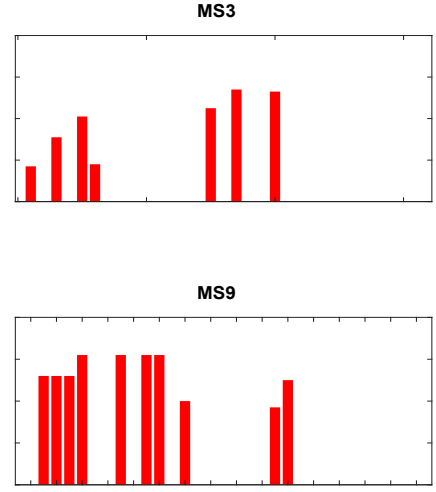

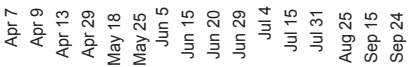

Figure 5. Spatio-temporal distribution of total number of scenarios for which computed IHS was acceptable across all the eight outlets during the water year. White cells that run from bottom to top show dates for which stream channel was dry.

\section{Discussion}

\subsection{Temporal Dynamics Reveal Passive Stores of "Old" Water in Perennial Outlets}

It is a generally accepted hydrologic notion in the Prairies that "old" water (which usually comes from passive storage of groundwater) is not expected to 

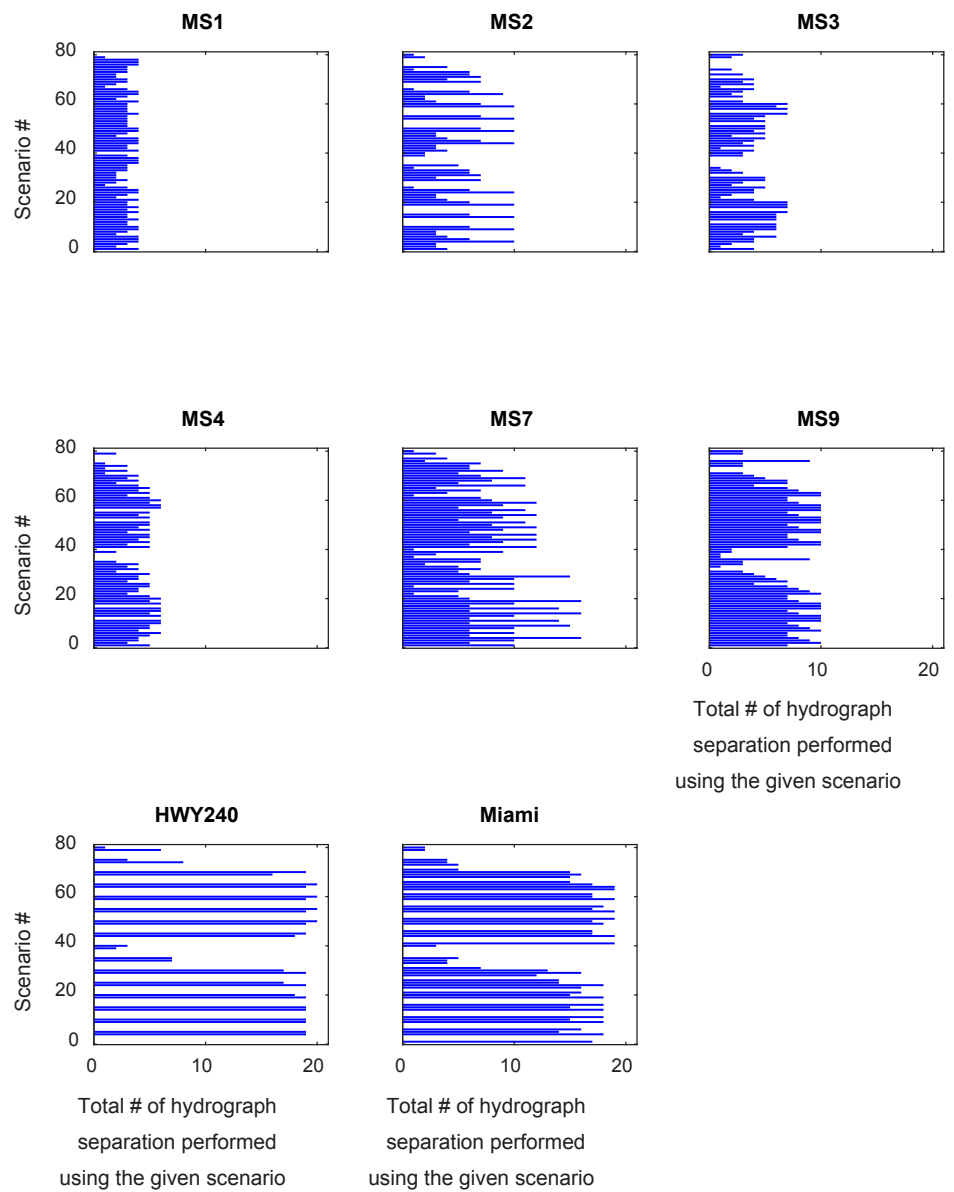

Figure 6. Distribution of the total number of hydrograph separation performed using the given scenario across all outlets during the water year. Note that the number of sampling days (as in Figure 2) has an influence on the totals shown in the current figure.

dominate in streamflow during the early and late spring seasons when snowmelt mostly contributes to runoff via Hortonian overland flow [16]. Melting of the accumulated snowpack from the long winter season (stretching from October to March) contributes significant proportions of "new" water to the streams during the freshet period. In the current study, however, we see a slightly different behavior in the only perennial outlet (HWY240) of the watershed; streamflow during the early spring season appears to contain unusually high proportions of $P R O P_{\text {old }}$ (Figure 2 and Figure 3). This we attribute to the passive stores of "old" water that was flowing in the stream from the prior fall season before the onset of the winter freeze. This passive store of "old" water was subsequently released, as part of streamflow, during the snowmelt period. This phenomenon was further made possible by the direct hydraulic connection (influenced by the intense fracturing resulting from the formation of the escarpment [Figure 1(a)]) between the streambed and the groundwater system at site HWY240. The connection further led to a quicker introduction of groundwater into the stream as the melting process continued. Field observation at site HWY240 revealed a quick 
(a)

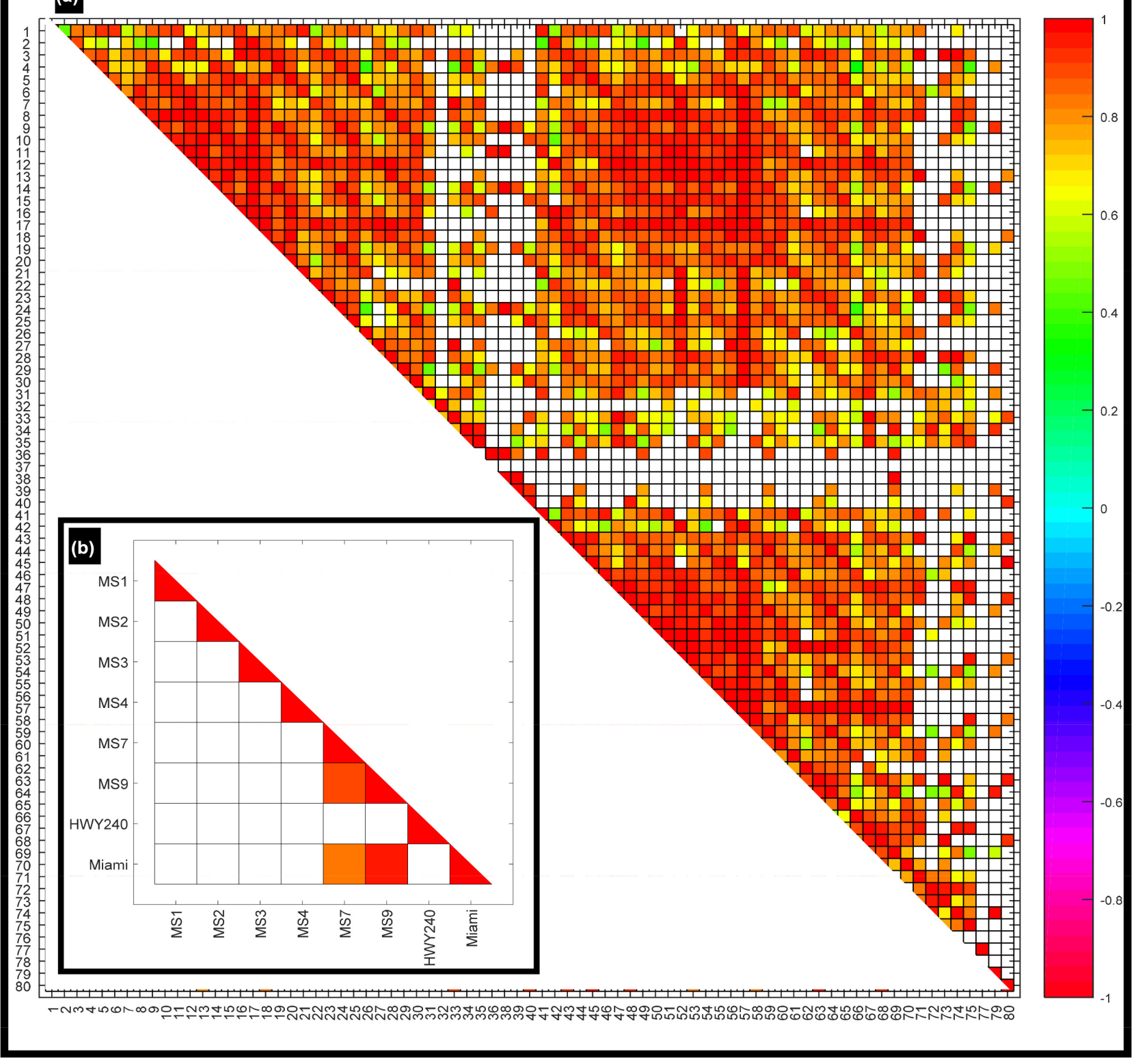

Figure 7. Correlation matrix showing the relation (or lack thereof) between computed IHS results across (a) all scenarios applied to the eight sites and (b) average results of all the scenarios within the sites. Blank cells represent Spearman's rank correlation coefficients that were not statistically significant at the $95 \%$ level.

snowmelt process (completed within four days) during the 2014 freshet; the average time it took at each of the other sites for all the snow to melt was about six weeks. This suggests that the relatively warmer groundwater, which was in direct connection with the streambed and possibly the vadose zones within the vicinity of site HWY240, actively contributed to the relatively quicker snowmelt process.

\subsection{Choice of Potential End-Member "Pool" May Vary Depending on Site Dynamics}

Making a choice-that make hydrologic sense-of potential End-Ms for IHS 
studies in seasonally cold and dry watersheds may involve diligence and extensive knowledge of the physio-hydrogeographic conditions of the site in consideration. This recent work has reaffirmed the fact that availability of streamwater samples throughout the majority of the water year, as observed at sites HWY240 and Miami in this case, may not necessarily yield reasonable IHS results when certain types of End-Ms are applied. Most of the considered scenarios (1 to 80) failed to yield IHS results within the acceptable range of 0 to 1 in those relatively larger catchments (i.e., HWY240 and Miami, Figure 5 \& Figure 6) where greater numbers of samples were collected. This is particularly the case for site HWY240, where the largest number of considered scenarios failed to yield IHS results that were within the acceptable range of 0 to 1 (Figures 4-6). It would have been expected that being the only perennial and potentially pristine outlet in this study, HWY240 would maintain a less variable "old" and "new" End-M dynamic throughout majority of the water year and thus lead to the selection of scenarios that would produce IHS results within the limits of acceptability. When it comes to the relatively smaller "MS" sites, a lot more possibility of choice of potential End-Ms exist within the "pool" of scenarios that yield IHS results that can be relied upon for purposes of watershed management, planning, and decision-making.

With regards to the associations of the $P R O P_{\text {old }}$ results across all the scenarios that yielded acceptable IHS results within all the sites, the strong and ubiquitous significant correlations suggests an interrelationship between scenarios when it comes to the IHS process. It is, however, important to state that during the apparent potential interchangeability of the scenarios in the IHS process, care must be taken to consider only those results that have uncertainty values [17] within an acceptable threshold. The observed significant correlations between the $P R O P_{\text {old }}$ values amongs some of the sites (e.g., MS9 and Miami) suggests a potential common site characteristics that may promote inter-site scenario transferability.

\section{Conclusion}

The main objective of this paper was to evaluate the dynamics of the potential "pools" of end-members that may be available to watershed scientists in the context of an isotope based hydrograph separation (IHS) process. We evaluated about 17,000 IHS results obtained by the application of a combination of a tracer (either $\delta^{18} \mathrm{O}$ or $\delta^{2} \mathrm{H}$ ), eight potential "old" water end-members, and eight potential "new" water end-members within eight nested systems of Prairie watersheds. It was observed that the application of some end-member and tracer choices at some of the sites led to high amounts of mathematically possible (including results that were below 0 or above 1) IHS results, many of which were unacceptable from a hydrologic standpoint. This dynamic was particularly true for the study sites that had relatively larger sizes and (or) were perennial in nature. We hypothesise that in those relatively larger and pristine watersheds, there 
may likely be more than two sources of contributions to streamflow, implying an application of a three-component mass balance equation rather than a two-component. This study also highlights a potential transferability of end-member and tracer choice applications across sites; implying that there could exist particular inter-site characteristics that promote the application of common end-member and tracer choices between those sites. The authors hereby urge watershed scientists that apply IHS in their work for watershed management purposes to pay detailed attention to the physio-hydrographic dynamics of their study sites in addition to a careful evaluation of the end-member and tracer choices they make.

\section{Acknowledgements}

This work was made possible, in part, by the award of the University of Manitoba Graduate Fellowship to the first author. Support was also made available by the Natural Sciences and Engineering Research Council of Canada (NSERC) through a Discovery Grant awarded to Dr. Genevieve Ali, the first author's PhD advisor. The authors thank the staff of Agriculture and Agri-Food Canada, who worked on the South Tobacco Creek watershed evaluation of beneficial management practices (WEBs) projects, for assisting in sample collection. We finally thank all the colleagues that analysed the water samples at the labs of the Manitoba's Watershed Systems Research Program and the Center for Earth Observation Science at the University of Manitoba, Canada.

\section{Conflicts of interest}

The authors do declare a no conflict of interest.

\section{References}

[1] Mohamoud, Y.M. (2008) Prediction of Daily Flow Duration Curves and Streamflow for Ungauged Catchments Using Regional Flow Duration Curves. Hydrological Sciences Journal, 53, 706-724. https://doi.org/10.1623/hysj.53.4.706

[2] Kneis, D., Burger, G. and Bronstert, A. (2012) Evaluation of Medium-Range Runoff Forecasts for a $50 \mathrm{~km}^{2}$ Watershed. Journal of Hydrology, 415, 341-353. https://doi.org/10.1016/j.jhydrol.2011.11.005

[3] Day, C.A. (2009) Modelling Impacts of Climate Change on Snowmelt Runoff Generation and Streamflow across Western U.S. Mountain Basins: A Review of Techniques and Applications for Water Resource Management. Progress in Physical Geography, 33, 614-633. https://doi.org/10.1177/0309133309343131

[4] Ye, S., Yaeger, M., Coopersmith, E., Cheng, L. and Sivapalan, M. (2012) Exploring the Physical Controls of Regional Patterns of Flow Duration Curves Part 2: Role of Seasonality, the Regime Curve, and Associated Process Controls. Hydrology and Earth System Sciences, 16, 4447-4465. https://doi.org/10.5194/hess-16-4447-2012

[5] Hugenschmidt, C., Ingwersen, J., Sangchan, W., Sukvanachaikul, Y., Duffner A., Uhlenbrook, S. and Streck, T. (2014) A Three-Component Hydrograph Separation Based on Geochemical Tracers in a Tropical Mountainous Headwater Catchment in Northern Thailand. Hydrology and Earth System Sciences, 18, 525-537. 
https://doi.org/10.5194/hess-18-525-2014

[6] Sklash, M.G. and Farvolden, R.N. (1979) Role of Groundwater in Storm Runoff. Journal of Hydrology, 43, 45-65. https://doi.org/10.1016/0022-1694(79)90164-1

[7] Buttle, J.M. (2005) Isotope Hydrograph Separation of Runoff Sources. In: Anderson, M.G., Ed., Encyclopedia of Hydrological Sciences, John Wiley \& Sons Ltd., Chichester, 10, 116 .

[8] Buttle, J.M. (1994) Isotope Hydrograph Separations and Rapid Delivery of Preevent water from Drainage Basins. Progress in Physical Geography, 18, 16-41. https://doi.org/10.1177/030913339401800102

[9] Bansah, S. and Ali, G. (2017) Evaluating the Effects of Tracer Choice and End-Member Definitions on Hydrograph Separation Results across Nested Seasonally Cold Watersheds. Water Resources Research, 53, 8851-8871. https://doi.org/10.1002/2016WR020252

[10] Tiessen, K.H.D., Elliott, J.A., Yarotski, J., Lobb, D.A., Flaten, D.N. and Glozier, N.E. (2010) Conventional and Conservation Tillage: Influence on Seasonal Runoff, Sediment, and Nutrient Losses in the Canadian Prairies. Journal of Environmental Quality, 39, 964-980. https://doi.org/10.2134/jeq2009.0219

[11] Bamburak, J.D. and Christopher, J.E. (2004) Mesozoic Stratigraphy of the Manitoba Escarpment. WCSB/TGI II, Fieldtrip Guidebook, 87 p.

[12] Pinder, G.F. and Jones, J.F. (1969) Determination of Ground-Water Component of Peak Discharge from Chemistry of Total Runoff. Water Resources Research, 5, 438-445. https://doi.org/10.1029/WR005i002p00438

[13] Hooper, P.R. and Shoemaker, C.A. (1986) A Comparison of Chemical and Isotopic Hydrograph Separation. Water Resources Research, 22, 1444-1454.

https://doi.org/10.1029/WR022i010p01444

[14] Metcalfe, R.A. and Buttle, J.M. (2001) Soil Partitioning and Surface Store Controls on Spring Runoff from a Boreal Forest Peatland Basin in North-Central Manitoba, Canada. Hydrological Processes, 15, 2305-2324. https://doi.org/10.1002/hyp.262

[15] Liu, Y.H., Fan, N.J., An, S.Q., Bai, X.H., Liu, F.D., Xu, Z., Wang, Z.S. and Liu, S.R. (2008) Characteristics of Water Isotopes and Hydrograph Separation during the Wet Season in the Heishui River, China. Journal of Hydrology, 353, 314-321. https://doi.org/10.1016/j.jhydrol.2008.02.017

[16] Fang, X., Minke, A., Pomeroy, J., Brown, T., Westbrook, C., Guo, X. and Guangul, S. (2007) A Review of Canadian Prairie Hydrology: Principles, Modelling and Response to Land Use and Drainage Change (Vol. 2). Centre for Hydrology, Saskatoon.

[17] Genereux, D. (1998) Quantifying Uncertainty in Tracer-Based Hydrograph Separations. Water Resources Research, 34, 915-919. https://doi.org/10.1029/98WR00010

[18] Craig, H. (1961) Standard for Reporting Concentrations of Deuterium and Oxygen-18 in Natural Waters. Science, 133, 1833-1841. https://doi.org/10.1126/science.133.3467.1833 